\title{
International Relations and/as thread-work: a dialogue on Threads, war and conflict
}

\author{
Authors: Selena Jamalullail $\checkmark$, Independent Researcher, UK, Roberta Bacic $\checkmark$, \\ Conflict Textiles, UK, Lydia C. Cole $\nabla$, University of York, UK, Laura Mills $\nabla$, University of \\ St Andrews, UK
}

Selena Jamalullail is an independent researcher interested in the intersection between art exhibitions and global discourse on politics. She attended the University of St Andrews during 2016-2020 and achieved a Joint Honours degree in Art History and International Relations. While a student, she participated in the Threads, War and Conflict exhibition at the Byre Theatre (St Andrews) as an exhibition tour guide.

Curator Roberta Bacic is a Chilean Human Rights advocate and researcher living in Northern Ireland. Since 2007 she has curated more than 150 international exhibitions of arpilleras in museums, universities, art galleries, embassies and community spaces worldwide. Over time, these exhibitions have expanded from Chilean arpilleras focused on the Pinochet dictatorship, to include quilts and other textile narratives of loss, resistance, testimony, protest and healing from around the world. The use of textile language in contested spaces has been at the centre of her curatorial work. In 2019 she curated, with assistance of Breege Doherty, Threads, War and Conflict, commissioned by Lydia Cole at University of St Andrews.

Lydia Cole is an Associate Lecturer at the University of York. Her most recent research has engaged with arts and global politics, with a focus on grassroots arts for change in Bosnia and Herzegovina. In 2019, she was Associate Lecturer at the University of St Andrews, where she commissioned and co-curated Threads, war and conflict, as well as coordinated and led its associated events programme. The exhibition featured arpilleras and textile banners from the Conflict Textiles collection.

Laura Mills is a Lecturer in International Relations at the University of St Andrews. She was a member of the Threads, war and conflict curatorial team, including staff co-lead of the Master's student workshops resulting in a collective textile for the Conflict Textiles collection. Her research explores how everyday life and culture are co-constitutive of global politics through examinations of cultural diplomacy, war, militarism, security, aesthetics and creative methods. Her first monograph, Post-9/11 US cultural diplomacy: the impossibility of cosmopolitanism, is forthcoming with Routledge New International Relations Series. 


\section{Abstract}

This intervention reflects on the opportunities for textile art, and its exhibition and making, to inform our study of conflict, violence, and resistance in International Relations. In a dialogue drawing on the Threads, War and Conflict exhibition at the Byre Theatre, St Andrews, this piece grounds our understanding of violence and its resistance through engagement with materials displayed at and promoting the exhibition. Our discussion of the exhibition and its associated events draws on metaphors of thread-work to explore the contributions of textile to international relations and the possibilities that textiles' material, affective and transgressive politics hold.

Keywords: textiles; textile exhibition; visual IR; curation; IR methodology; arpilleras

From 3-29 April 2019, the exhibition Threads, war and conflict brought a selection of conflict textiles from around the world to St Andrews, Scotland. ${ }^{1}$ Hosted by the University of St Andrews' School of International Relations in collaboration with the Byre Theatre, the exhibition and its associated events programme aimed to explore war, conflict and its many layers of hope and suffering. Featuring a selection of textiles from the Conflict Textiles collection, ${ }^{2}$ including arpilleras $^{3}$ and protest banners, the exhibition was curated around key topics addressed in the School of International Relations including resistance, the ethics of warfare, and migration and displacement. The process of curating the exhibition and its associated events unfolded organically, drawing together students, academics, Scottish cultural institutions and interested members of the public. Not only did this process create space for conversations around the diverse topics of war and conflict addressed with(in) the textiles, but it also provided rich opportunities for collaborative teaching, research and engagement. These opportunities resulted in several collaborative outcomes from the exhibition, including an international academic-practitioner workshop at the Byre Theatre, and a collective textile made by students and lecturers from Scottish Higher Education Institutions across a series of workshops, which will now join the Conflict Textiles collection.

The conversations and collaborations inaugurated in St Andrews continue within this dialogue and, indeed, in the Special Issue as a whole. This creative opening more specifically takes the form of a dialogue between Selena Jamalullail, a School of International Relations student who served as exhibition tour guide and participated in the collective textile workshops associated with the exhibition, and Roberta Bacic, curator of the Conflict Textiles collection. Lydia Cole and Laura Mills, two members of the Threads, war and conflict team, tied together the threads of their conversation. This approach enables insights from a crosssection of those engaged in the exhibition to be woven together in order to reveal and unpick how curating the (hi)stories of conflict textiles can produce alternative ways of knowing and doing International Relations (IR). 
Over a year since the exhibition, this dialogue reflects back, beginning with a discussion of the textile workshops, then moving to explore the exhibition, its curation and its pieces. In this way, this reflective dialogue unravels the threads of war and conflict examined in the exhibition and its associated events. Throughout, the dialogue draws upon the language associated with thread-work to explore the tactile, emotional, interactive, non-linear, symbolic, transgressive and politically powerful qualities of the exhibition, its featured textiles, and the textile-making it enables. It does so by engaging with material artefacts of the exhibition the collective textile workshops poster, the events programme bookmark, and the textiles themselves - to demonstrate how they produce these material effects for arpilleristas and makers, for exhibition curators and visitors, and for students and researchers of IR.

\section{Unravelling and (re)connecting in Threads, war and conflict}

Selena: Focusing on Threads, war and conflict, I'd like to initiate a dialogue with you about the opportunities that textile art exhibitions offer to inform our study of conflict and violence; particularly how they offer alternative narratives in IR through stitching stories of resistance. Specifically, I'd like to focus on how textiles and weaving offer a discursive method, a different language. Looking now at the poster for the Master's Textiles Workshops (see Figures 1 and 2), I am interested in approaching our discussion from the exhibition's outcomes and tracing back to the beginning of Threads, war and conflict.

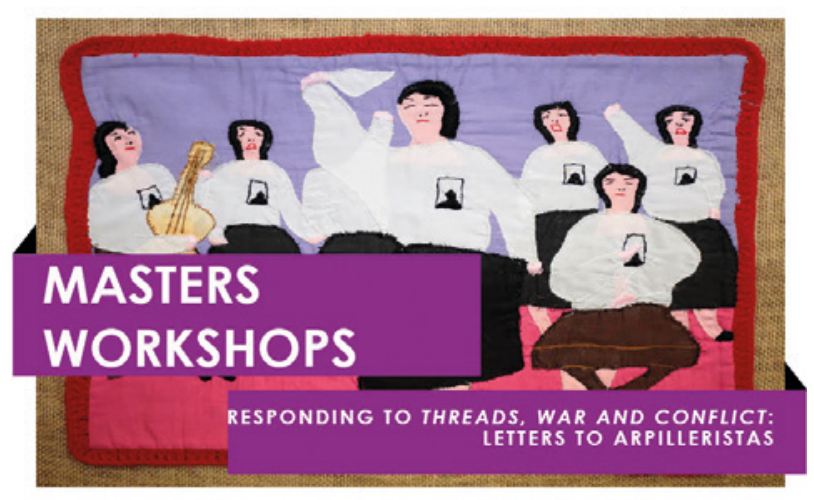

Over 3 workshops, International Relations and International Security Masters students will work with a textile artist and lecturers in the University of St Andrews School of International Relations to create a collective textile responding to the themes of the Threads, War and Conflict exhibition. Inspired by arpilleras with concealed letters from their maker, students will create an envelope and letter which will comprise a larger textile that will become part of the Conflict Textile archive.

TO APPLY, SEND A STATEMENT OF

MOTIVATION (max. 250 words) TO: DR LYDIA COLE (lcc6est-andrews.ac.uk) \& DR LAURA MILLS (ljm33@st-andrews.ac.uk) BY 5PM on 22, FEBRUARY 2019.

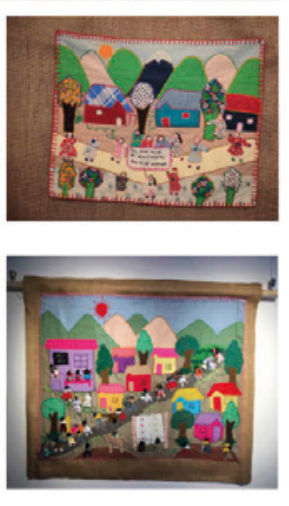

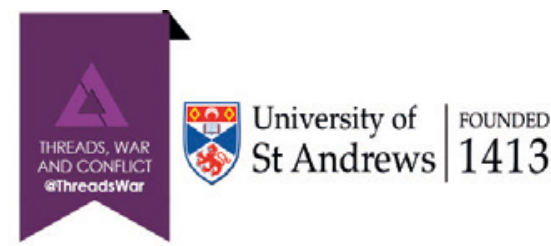
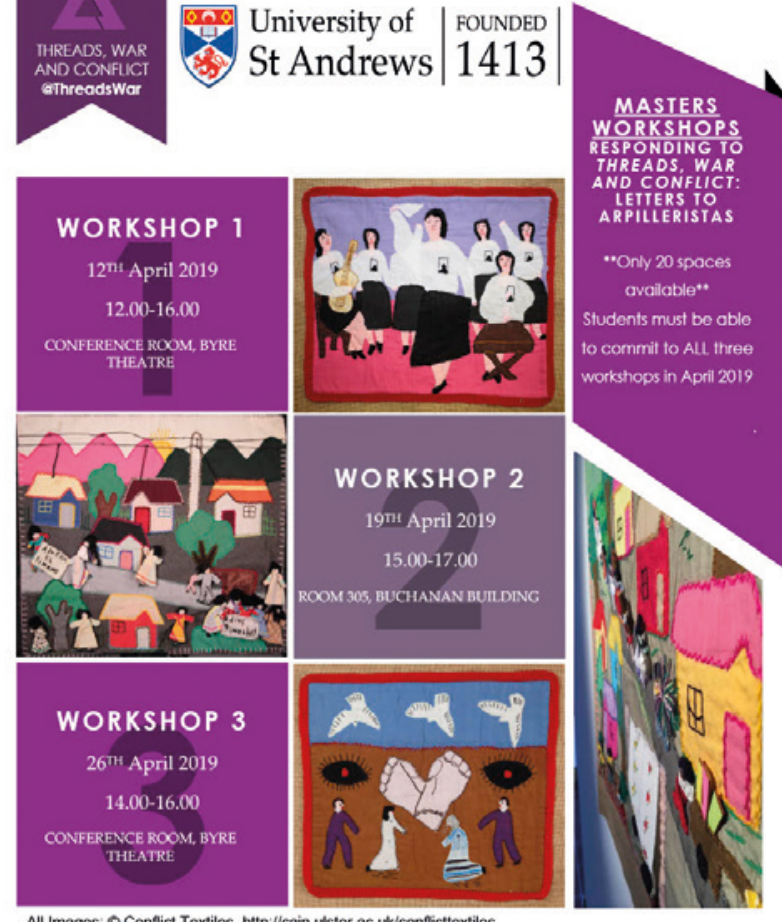

Figures 1 and 2: Poster for Responding to Threads, war and conflict: letters to arpilleristas, Master's Textiles Workshops, University of St Andrews, 2019. Images: Conflict Textiles and Laura Mills. 
Roberta: I find it very original the way you are going to deconstruct from the outcome, and to see how much was predictable or not predictable because the plan will not always turn out as we expect it.

S: Yes, I am interested in seeing how there are changes and unexpected events, which always arise when events are realised. This poster documents the workshops that accompanied the exhibition, in which a group of students came together for three workshops to create a collective textile inspired by the exhibition. Local textile artist Sheila Mortlock provided materials and some techniques, but we could use our own creativity, ideas and exhibition inspiration to influence our works.

R: You had to relate to the exhibition. You had the space from where to connect and from where to be creative, but you were given a framework.

S: It was inspiring to see the diversity of pieces in the exhibition and how they related to one another. We all participated in creating the collective textile but through the making of our own individual pieces, through our interpretation of the workshops' prompt, as well as our own understandings and meanings of resistance, violence and political conflict. The content of the arpilleras that resulted from these workshops was just as diverse as the pieces in the exhibition. How do you go about drawing these various threads, or pieces, together within the exhibition itself?

R: What is important is the relationship of the curatorial line. The title of the exhibition determines the way you choose which pieces to display. It relates to the way you relate to the topic. Each piece is not chosen at random but in fluent connection to the issues that you want to portray.

S: Do you feel that textiles and exhibitions become a form of expression? Does approaching the study of IR through these lenses - through looking at those creating these works - offer students, exhibition visitors and other viewers a new perspective?

R: I don't know how much of a new perspective it is. Sewing has always been there, and the reflection you do while sewing is there, but it hasn't been incorporated as a discourse or a language that could give you information on content, feeling and experience. In the last few years, there has been a resurgence of this kind of discourse, and a recognition that we have multiple capacities to express - because what happens to us touches us in so many ways. The textile gives you this incredible capacity to work through your emotions. So, it is not this line from beginning to middle to end; you go around instead. Some textiles get special attention because they deal with memory, resistance and narratives. They can do many things when you learn to talk through them but also when you learn to read through them. So, it is not only to be able to express it, but also to decipher it. You will not always be able to respond 
with sewing but very often you will need to be able to read other forms of communication in the sewing.

S: Definitely. As someone who was involved with sharing the exhibition with others, you realise how you can perceive a story from its visual depiction. It requires participation to understand the piece: coming up close to it, inspecting, discussing with others. In these workshops, it took a long time to put together something not only visual but also deliver something tangible. The engagement with the pieces was really key.

R: I think what is also important is that the narrative is intertwined with the technique with which you are going to tell this story. You are using a needle. You are taking action. I think for many of the arpilleristas, the idea that they could take action in front of a state that would not listen to them, would not do things for them, would deny the events, the sole exercise of being part of the dynamic process of acting gives a power to the discourse.

S: And that contributes to the understanding of its subjects and themes as active.

Threads of resistance: the textile language of Chilean arpilleras

S: This segues into our first textile piece (see Figure 3).

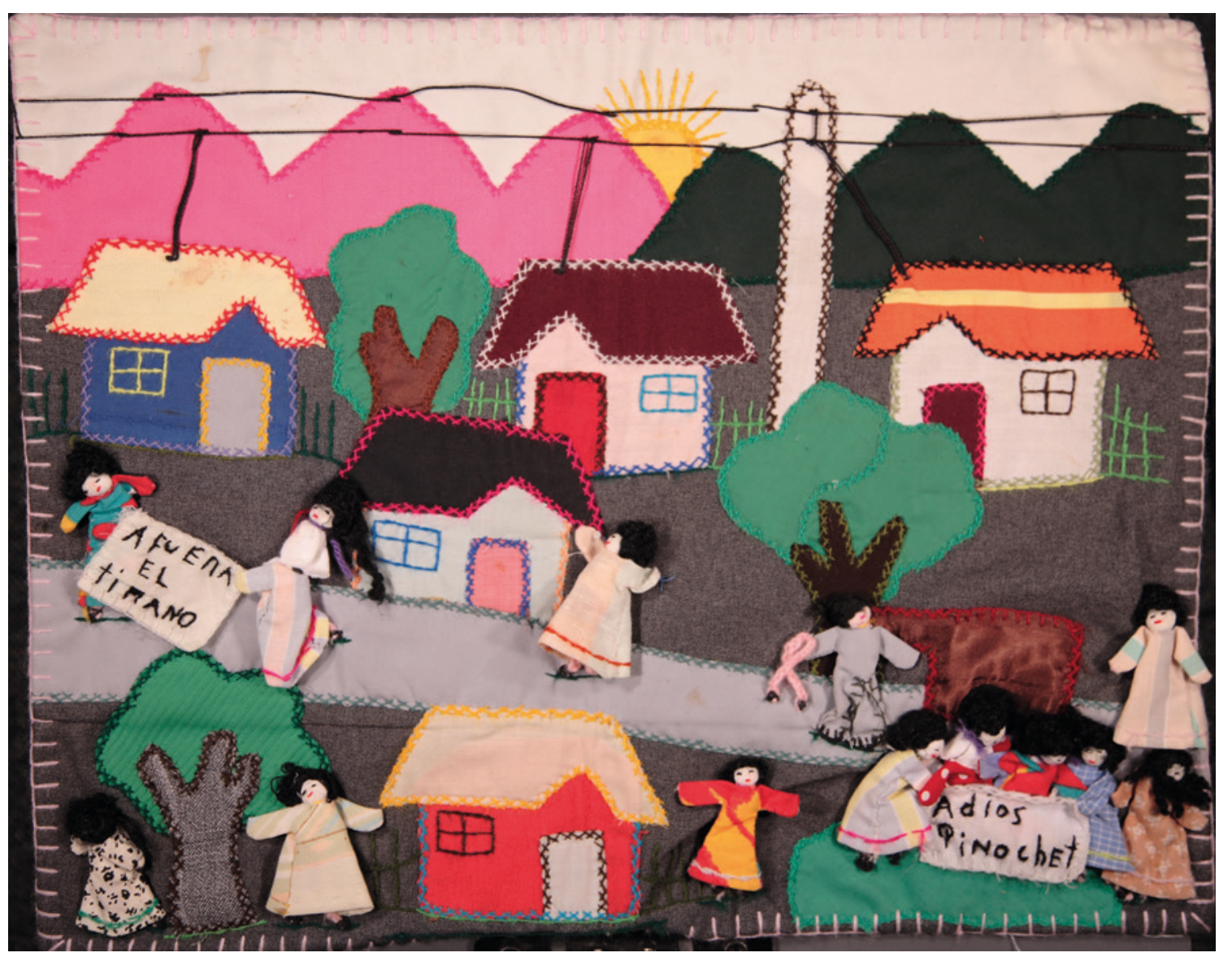

Figure 3: Anonymous (c1980) ¡Adiós Pinochet! / Goodbye Pinochet!. Arpillera, Chile. Photo Colin Peck, (C) Conflict Textiles 
S: I remember this piece dearly. It has such a specific place in history that you can trace within it. Can you explain a little bit more about this piece?

R: This is an example of a Chilean arpillera: three-dimensional textiles from Latin America, of Chilean origin, which became a medium primarily for women to denounce the human rights abuses and repression of the Pinochet dictatorship in Chile, 1973-1990. In this particular piece, there are many readings and layers. There is a cultural landscape. You can see we have the mountains which guide us to understand we are in Chile because it is the Andes - that determines where you are physically. The other element important here is the sun. In spite of all these difficulties, the sun is there for the people. As a symbol, it has a political connotation: the sun rises for everybody, it makes no distinction. These kinds of textile - the arpilleras - also incorporated specific elements that we can read and decode. We have the electricity cables and you can see people tapping into the electricity, highlighting the disparity of access to these resources. So that locates us immediately in the shanty town where people are taking action, living daily life in conditions of poverty.

Another important element is the simplicity of the stitch and the materials. It requires that you understand and are able to read those twists in the language, that those scraps of material hold meaning. The grey material you see on the ground is from school uniforms. The blanket stitch on the border marks this as a picture, a picture that you want people to look at. But the message is very clear. What makes this so interesting is that this is very tactile but on the other hand the discourse is very direct. It is not sophisticated. It is an example of direct language and demands: out the tyrant! They are not making aggressive accusations, they are saying: "Just go, goodbye Pinochet". They are not speaking about revenge because they don't believe that they have the time or the energy for that, but they find that their actions could aid the removal of Pinochet. I find it very powerful that this piece has been able to be in the most incredible spaces. It was in the Victoria and Albert Museum in the Disobedient objects exhibition for a few months. ${ }^{4}$ Thinking about the textile through the lens of a disobedient object, against the idea that women should be silent and at home, we also see a message of transgression: to go beyond what is expected of you or demanded from you, you can live it and relive it in your own context.

S: When I remember these pieces, I recall how some of them were done in secret, hidden away or smuggled elsewhere.

R: They were smuggled, as well as bought, by volunteers and people of good faith who wanted to support the women and the movement and wanted to contribute to denouncing what was going on in the country, which was being hidden by the economic success in the beginning through statistics. This didn't mean that life was good for these women. Because 
they didn't count. If you keep them hidden and silent, then if one person earns one thousand and the other nothing, you still have a good average of five hundred and that makes it okay.

S: I see these pieces as forms of resistance. In this piece, they are not proposing violence, but it is still a form and subject of expression that was suppressed. To be able to do these pieces is a reflection of them trying to assert their own voice and identity. I remember this piece, La cueca sola (see Figure 4). The creator, Violeta Morales, was well known, a prominent activist. The dance that the textile piece depicts was also a form of resistance. How can we interpret this resistance in the form of textiles and stitching?

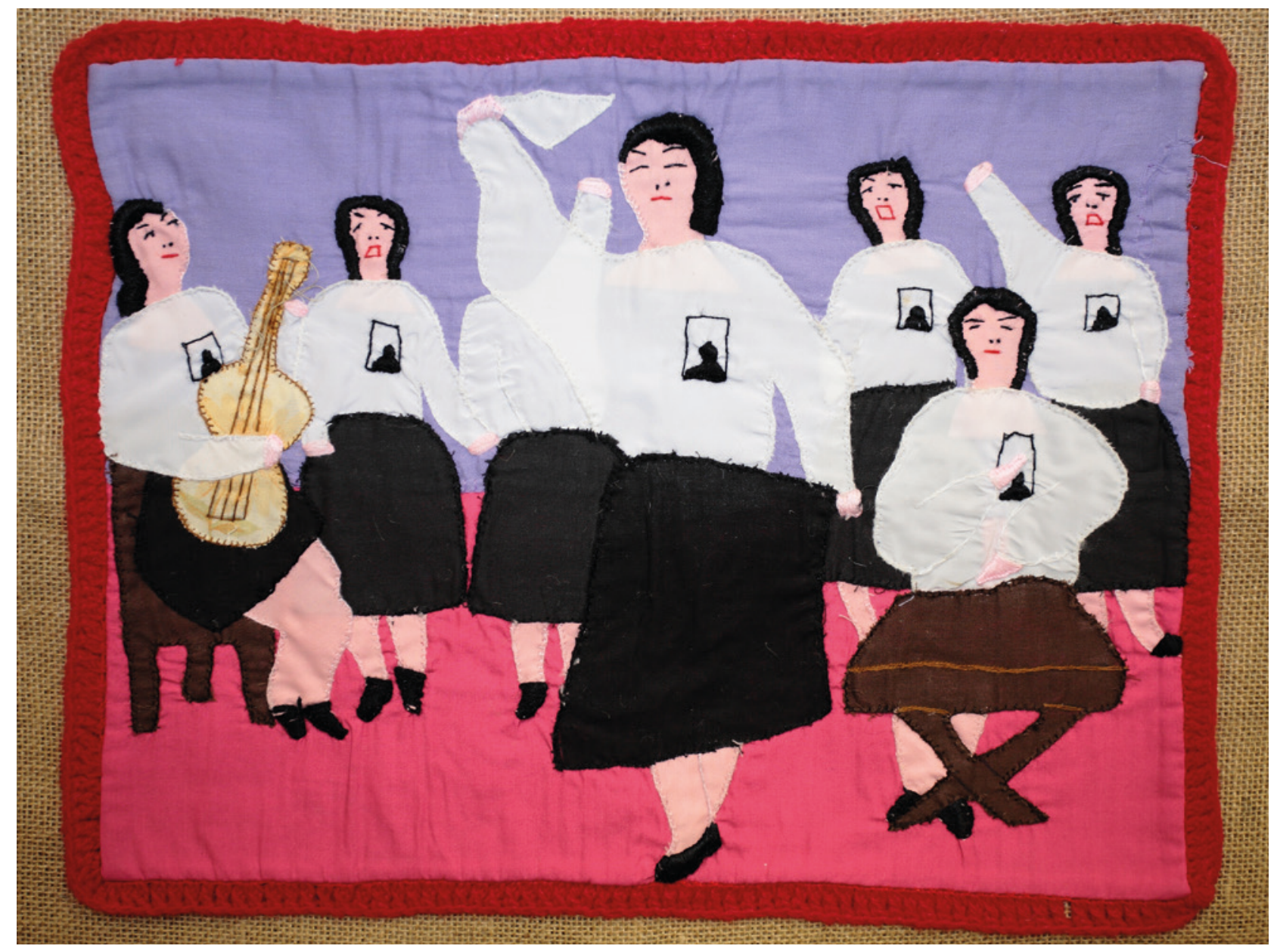

Figure 4: Morales, V. (1989) La cueca sola / Dancing cueca alone. Arpillera, Chile. Photo: Martin Melaugh, (c) Conflict Textiles

R: In the case of Violeta Morales, she was a very active woman. She used all the mediums she had at hand to denounce torture in Chile. That was her fundamental denunciation because her brother had been disappeared and the people she had interviewed, who came out of the prison where her brother had been, were talking about torture. She used the arpillera, she used marches, she used singing, she used dancing. She was extremely purposed, acted very strongly, and became part of a performance group that undertook these actions in public space outdoors, not only indoors like this textile that she made. They would have danced in the streets of Santiago, knowing and wanting to be arrested, to denounce what was going 
on to the people in the streets as they were oblivious. What they wanted was to occupy the streets and to bring into public knowledge what was going on in parts of Santiago most affected by the dictatorship.

S: Did the production of these arpilleras see a spike at the time? Their creators had lost their husbands, brothers and other family members who were disappeared. Left behind, they chose to create these arpilleras. Is it because of these circumstances that we see so many of these textile pieces from Chile?

R: They were not popular in Chile. You couldn't have them; you couldn't show them because they were considered subversive. What happened is the dissemination of arpilleras with the production of many more occurring thanks to the international solidarity movement that decided to support the women because they also needed to earn a living. Women had no jobs; their husbands had disappeared or their sons couldn't do it. Through these networks, they also got a bit of income. So, it becomes a denunciation, but also a way of earning their life. Many groups, like Amnesty or Caritas, and international organisations in the UK would have acquired arpilleras and sold them amongst solidarity movements in England with three intentions. First, to help the women financially. Second, to spread the news of what was going on, using them almost like a newspaper. Third, to create networks of support internally in the country and externally acting together. It was those networks, especially in the UK, that helped to gain asylum for Chileans who were in prison. The only way to be released was if they were able to go somewhere as refugees. The arpilleras were just one of the voices among other expressions. The power of this was in the possibility of commercialising, discussing, exhibiting them, and creating these networks of solidarity.

S: Do you think that because of the conditions - that they had to create the arpilleras with scrap material, needle and thread - the arpillera was a particularly accessible medium for these women to create and engage with these networks, and then earn a living?

R: Well, one of the prides of the arpillerista is not to buy material. The use of these scrap materials is symbolic. They are scraps of your own or a loved one's clothes. Violeta Morales once gave an interview where she said they were so poor that they would cut pieces of their blouses. It is the opposite of the concept of a quilt-maker, who would have so much material and would always pick the one that fits best. They did with what they could, and they were proud of themselves to be able to produce these with very little.

\section{Threads of anti-militarism: from the local to the global}

S: These two arpilleras come from the particular context of the Pinochet regime. This next one, Digital death, is much more contemporary (see Figure 5) and was made in Ireland. Do you see crossovers with how the arpillera is used? Is this creator also trying to do the same thing or is it completely different when it comes to materials and style? 
Figure 5: Stockdale, D. (2014) Digital death. Arpillera, Republic of Ireland. Photo: Martin Melaugh, (C) Conflict Textiles

R: It is not. I am very happy that you chose this one for our discussion. Deborah Stockdale is a textile artist who has made quilts and has expressed herself for forty years with textile art. She had done pieces that were about different issues, even social issues, but she hadn't positioned herself like how an arpillerista does. When she found the arpilleras, she found another way to stitch about what was going on in the world. To use a language very comfortable for her to tell uncomfortable stories. It

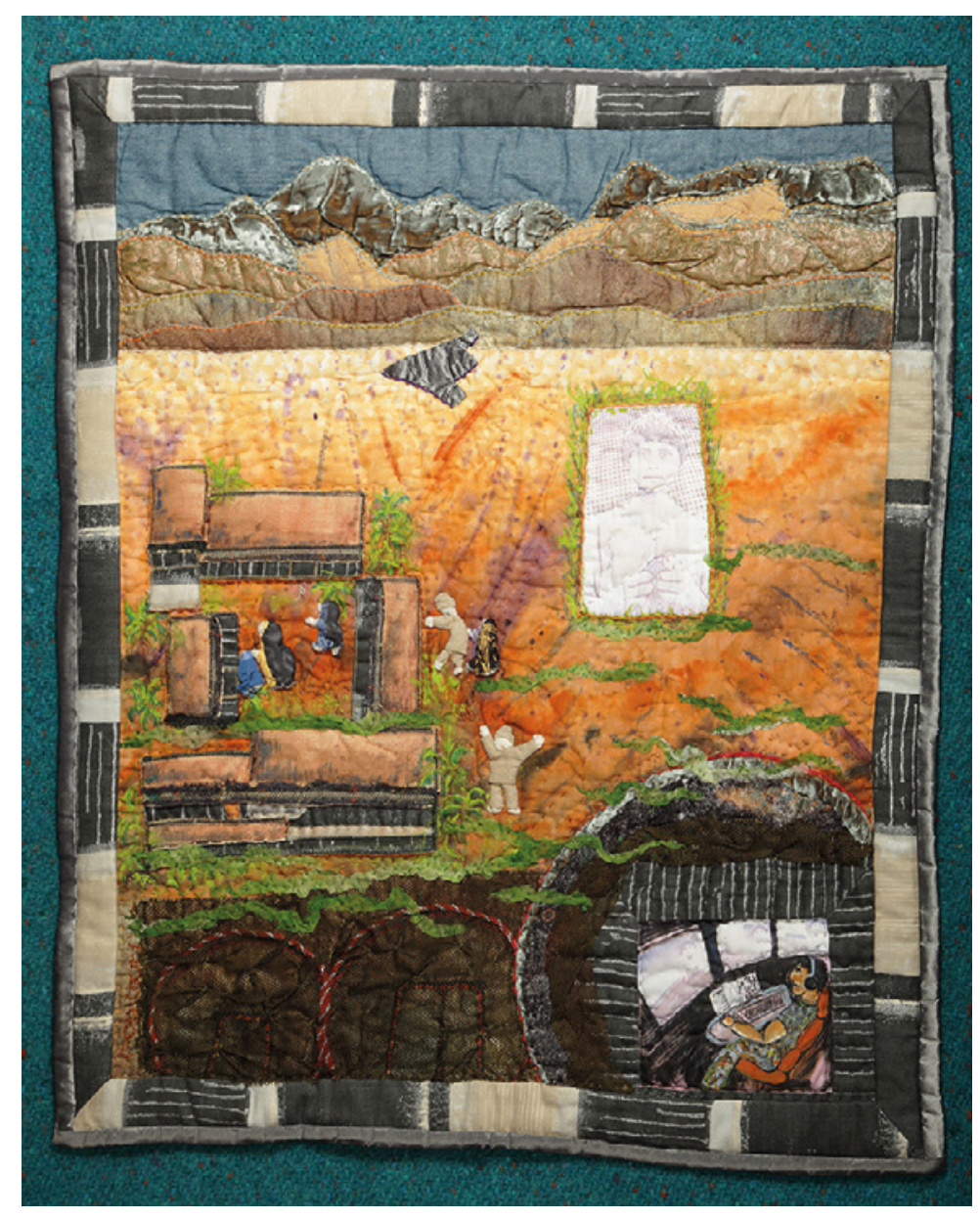
was as if she thought: "If the Chilean women can do it, I can also do it. I can create what I need to create."

This piece is very symbolic in the sense that its genesis was in my home, in a discussion with two friends involved in a movement for the abolition of war, about the use of this violence, that can be done so comfortably from home, from computers. We now have the possibility for one person in one country to decide who the target is going to be and where. That you can destroy whole villages because you want to destroy one person. This piece is in response to that. Stitching is like your own handwriting. Though you and I might have the same pen, it will come out differently. Here, Deborah is reflecting, responding and engaging with the arpillera language with her own kind of perspective and through her own research.

S: Yes, her own mark. For me, this piece is more explicit than those previously discussed, but is also as emotionally impactful on the viewer. How do you think this piece represents conflict and violence differently?

R: For me it is a reflection, it comes from a deep conversation, trying to embrace the consequences of war through technology and being "so sophisticated". For those who suffer the bombing on the ground, it is not going to be so sophisticated. You are going to be destroyed and you won't even know where this comes from, you won't even be able to respond. The other textiles we have discussed were explicit in different ways - wanting Pinochet to go. 
Here, we have an image of this man comfortable in his office, listening to whatever he is listening to, the drone targeting the village and people afraid because they can hear the drone. I can relate this very much to the carpets made in Afghanistan that depicted the plane bombings in a time when there were no mobile phones or cameras to take photographs of these bombs. They were woven as a kind of picture and could even be used in court as a kind of testimony to demonstrate who had come to bomb them.

Yet, Digital death is quite a composed piece. It reflects the people and action from a distance. Unfortunately, from the textile we don't see the colours of the image of the girl. It is very blue in real life. This is important because this represents a 2014 art installation called \#NotABugSplat..$^{5}$ The installation is of a massive photograph of a girl who lost both her parents and two young siblings in a drone attack. The artist collective who created the installation placed it on the land in the heavily bombed Khyber Pakhtunkhwa region of Pakistan so that when a drone flew overhead, they could see this girl as a remembrance of the survivors and innocent victims. It is full of different materials, and to make this piece, Deborah researched a lot, even down to the proportions and sizes of the characters and objects.

S: The next textile also speaks to the role of technology in today's conflict. It's no ****** computer game!! (see Figure 6) is striking for its colours. It has a silk fabric that immediately gave me the impression it was more contemporary, but its subject also reflects our distance from conflict in the world.

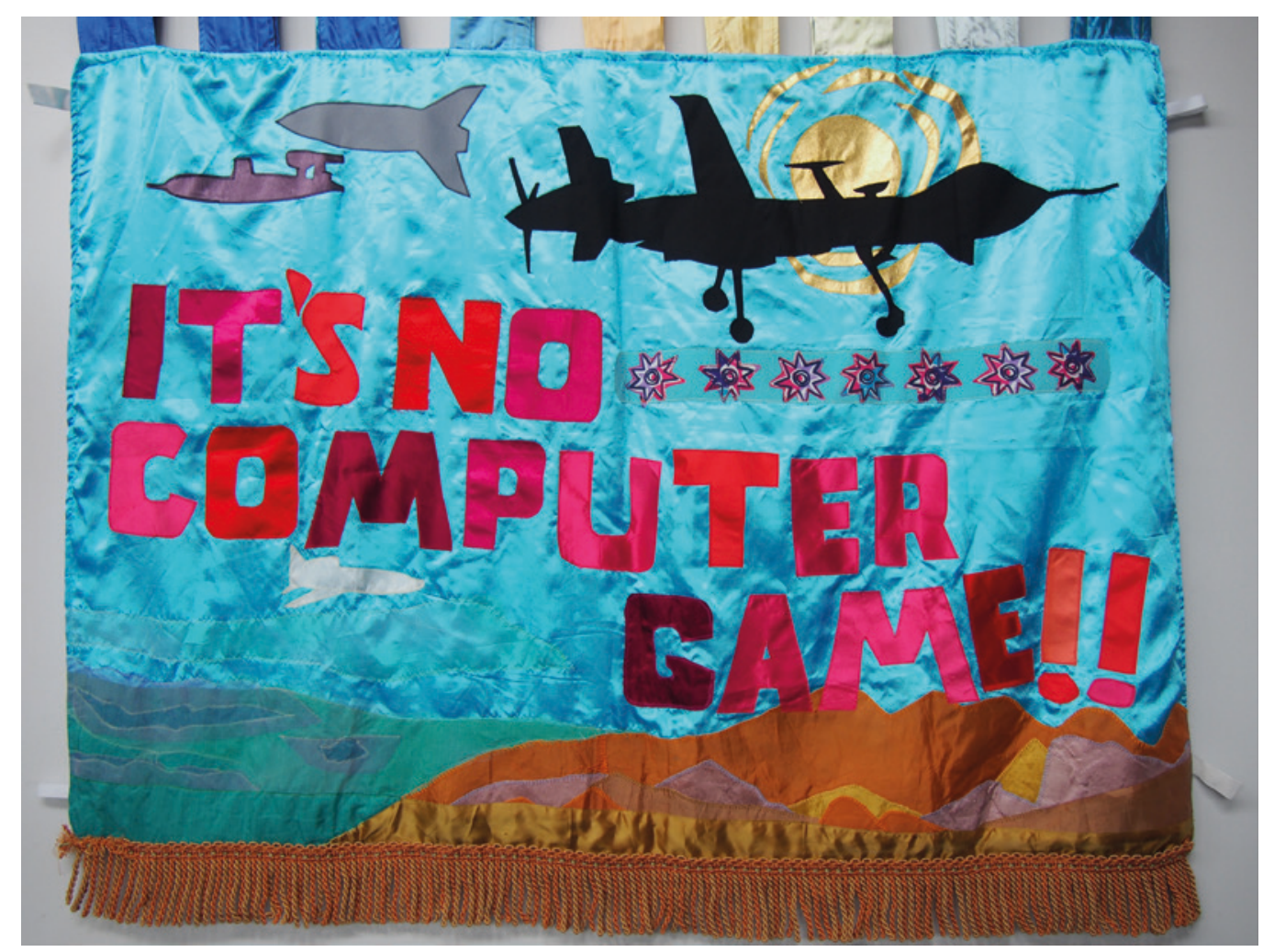

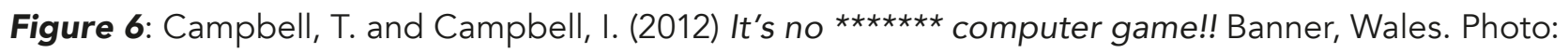
Lydia Cole, @ Conflict Textiles 
$\mathbf{R}$ : The difference lies in the purpose of the textile. This one is a banner, so it can be used to march and denounce, while the other is a picture. I find this a very powerful piece and Thalia and Ian Campbell have been very active members of so many movements in the UK which have denounced militarism.

S: To me this is interesting because today we are so used to seeing posters, images, photographs and videos. This was made in 2012, so it is fairly recent compared to the Chilean arpilleras. What do you think is the difference in understanding of the message when it is displayed on something that has taken a lot of time to make, like this banner, as opposed to a poster for a protest?

R: I think some people learn better by reading, others by hearing. I think you have to use all the systems that you can, and you have to try to engage people from all their senses and their abilities. I don't think one alone is better than the other. It is the different uses of expression. I think it is the effectiveness and the right moment to use it in the right place. It is not very easy to go with a big banner to a small meeting. You need space and time, and you need to locate the pieces in the context in which they can be appreciated.

S: What do you think it offers the creators of such pieces, since it takes much more time for them to create a textile such as this versus making something on the computer in a matter of minutes to print?

R: I think it is your own way of contributing to a cause or to express yourself. Sometimes you can take many photos and you don't like any, you don't feel any represents what you wanted to say. This is the long-standing purpose from beginning to completion. In textiles, you only see the pieces that are completed. You have to have the momentum for that. Making is a process, you must have a trigger, you must have internal space, physical space, an environment of support, in a way that at least lets you do it.

\section{Threads' emotional, tactile and intimate politics}

S: This next piece, My daughter's wedding, was created in a workshop (see Figure 7). It is made by a mother who depicts her daughter's wedding that she could not attend because her documents were revoked. The piece can be connected to the increased hostility surrounding immigration in Europe. 
Figure 7: Mansouri, F. (2017) LA BODA DE MI HIJA / My daughter's wedding. Arpillera, Catalonia, Spain. Photo: Ricard Díez, (C) Conflict Textiles

$\mathbf{R}$ : Yes, it was made in a workshop in Catalonia. It also demonstrates how sometimes you can be deceived by the image, the colours and everything, depicting something so beautiful, but you have to be careful what you read because behind the scenes there might be something different happening.

S: What role do you see emotion

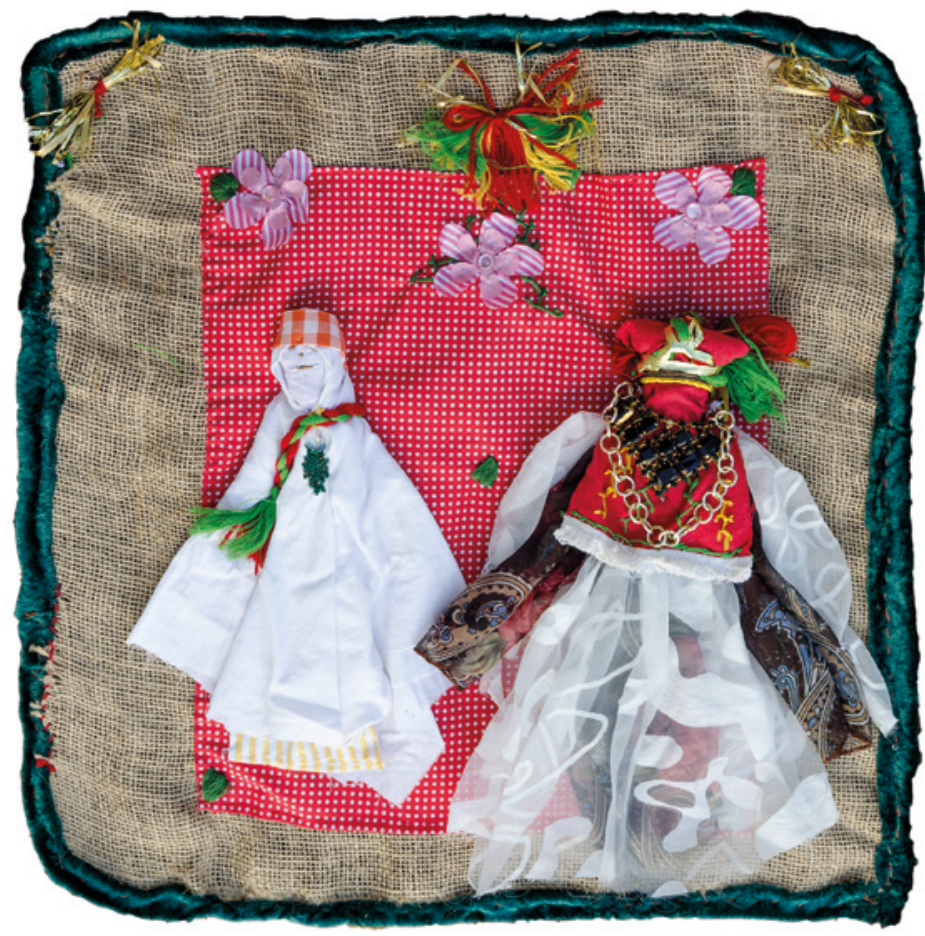
playing in this particular piece and in the wider significance of textile-making?

$\mathbf{R}$ : I think the emotional is always present in the tactile element of the textile. Don't forget that there are two things you have to do every day of your life: dress yourself and eat. Textile is thus something quotidian that will appear in everything. Interestingly enough, I was talking to an artist yesterday about the times that we are living in. Issues related to the environment and Covid-19 are showing us the importance of reusing and repurposing materials. That we can't continue polluting, using disposable throwaway items, paper napkins and all of that. I think we will also see a recurrence of textile work. I have begun organising exhibitions online in response. We have been encouraging people in lockdown and/or staying at home to engage and use what they have at hand. So, it is also an opportunity to reflect on how we can express our emotions and our actions by using what we have on hand. I usually say: 'No list, just bring scraps of materials and you will find you have more than you need'.

S: If you completely rely on what you have and don't search for any fancy materials, you realise that it is hard to distinguish which periods these textiles are from. Materials are materials.

R: This piece as well has so much volume and texture. When choosing pieces with Lydia for Threads, war and conflict, we had to find pieces that appealed to our curatorial line, with its common thread of everyday experiences of war and conflict, and its layers of hope and suffering. This included textiles about bombs, lack of free movement and hunger. It is important that we can weave these textiles together to show what is happening. 
S: I agree. I love this textile for how three-dimensional it is. It goes to show that you can really think out of the box and get creative when it comes to sewing and needlework. It also speaks to it as a form of language. This is also so interesting, as some of the makers did not have prior experience in textile-making or thread-work. In that sense, textile language is not two-dimensional; it has many variations.

R: I always say that the little mistakes you have in sewing are like spelling mistakes. The more practice you have, the less spelling mistakes you have. It is another skill, another language, another technique. Sometimes we are told that we have to be proficient in everything. But if we give it patience, time, a little dedication and value, you discover things within yourself. The value of the textile lies in more than just its looks. Not everything in life is beautiful either. Some pieces appeal to you because of their modesty!

S: I definitely find that the mistakes we identify in the textile are probably the most interesting because they remind you that someone hand-made them. This also tells a story.

\section{Connections, collaborations and curating in Threads, war and conflict}

$\mathbf{S}$ : This brings me to our final piece: the bookmark outlining the exhibition programme (see Figure 8). Why did the organisers choose to do a bookmark to represent the programme?

Figure 8: Bookmark with the Threads, war and conflict programme. University of St Andrews, 2019.

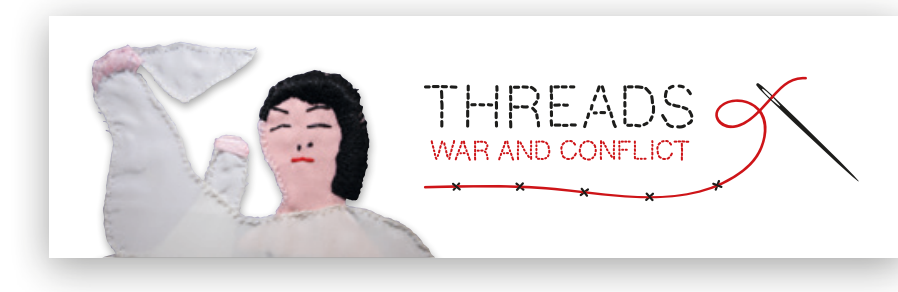

R: Conflict Textiles have been featured on bookmarks for a while. A bookmark is usable. It is not just for the opening of the event. The beautiful thing is you can keep it over the years, a reminder. On the other hand, it's a nice exercise to write the programme with brief enough information to make you want to know more. If you look at the bookmark, you can see a stitch that details each activity.

S: Yes, the visuality of the logo and stitches marking each event becomes a powerful thread itself. Can you speak a little bit to the time of curating and creating this programme? What was that process like?

R: Well, it was quite organic. So, it wasn't an exhibition that came ready made from Northern Ireland. We went physically, myself and Breege, Assistant Curator of Conflict Textiles, to St Andrews and spent two full days with the organisers, giving them space and time to talk about what they expected, and what they wanted to do with the exhibition. That is what started it, involving everyone with the role of curation, helping each other, collaborating and 
building. Then adding ideas about what would be significant for the kind of topics they were developing in their lectures, connected to the students that were there at the time, because it is very versatile material - at once so ordinary yet so sophisticated - that can speak to people across different backgrounds, experiences and perspectives.

S: Yes, we had some researchers and academics, but we also had Master's students and the general public.

R: This connection of different voices was extremely good, and we agreed from the beginning to have a satellite exhibition in the University library, so that people could know that even though it was an arpillera exhibition with materials that were very simple, it had given space for lots of research, scholarship and interpretation. Everybody has to live their lives, there is no more or less important life. It is how you can engage with what you do in daily life. So that was the idea, and also to space them in a way that the exhibitions in some way, for me, are an excuse for all the activities that take place during the time - to have the conversations, the workshops, the visits, the challenges, and keep the momentum from beginning to end, and that the end is never a conclusion but only the last step of this part of the process.

S: Do you have a final take-away from the St Andrews exhibition at the Byre Theatre?

R: I would say it was a very well-lived exhibition. All the times we spent together were extremely enjoyable and, I would say, smooth, even in the most difficult moments. There was always a warm atmosphere of being involved; we were all in the same boat. That is something that sewing gives you; there is not this competitive element that is so often pervasive in academia. Here, everybody helps the other, it comes naturally. We were all there to accomplish this, and I valued very much when, for the opening, we also had a textile artist who had worked with me in Liverpool. She had come from a very remote part of the end of Scotland, to be here after ten years of not being involved with arpilleras. So, we brought together new and old voices. We renewed commitments. And after St Andrews, she came to the launch of my exhibition here in March and contributed a doll that she had made twentyfive years ago. There is a sense here that textile triggers emotions. It triggers an exploration of memory, both of what has happened and been happening. Although in this moment you may not be sewing, it brings to mind memories of when you have before. For example, you may have told the stories of losing relatives you love through the language of textile, using a piece of cloth from the T-shirt of your father. Experiencing the textiles through an exhibition can bring all this to mind. That triggering of emotions and experiences was extremely well achieved by this exhibition. I also think Lydia had a very good team, knowing exactly what she was after, but also flexible, not just working toward the final goal. Each exhibition is owned by the collective that organises, prepares and lives it, and then has it there as a testimony for the future, because in our archive it is there forever. Our exhibitions are always an invitation to participate, not just to be a spectator. 


\section{Conclusion: tying threads}

This dialogue has traced the Threads, war and conflict exhibition in reverse - from outcome to opening - to unravel the possibilities of International Relations and/as thread-work. Framing itself around material artefacts of the exhibition - the collective textile workshops poster, selected textiles featured in the exhibition and the events programme bookmark - the dialogue weaves together the various threads of their material effects. The discussion of the collective textile workshops and exhibition events has placed emphasis on the collaborative participation within the exhibition. This was particularly borne out in the textile workshops in which students and academics across Scottish Higher Education Institutions produced textile responses to the exhibition. Participants engaged as arpilleristas, responding to themes of home, loss and resistance to violence within the resulting textiles. From the beginning, participants knew that the textile would form part of a broader collaborative textile to be archived within the Conflict Textiles collection. This mode of collective making not only generated renewed understandings of the arpilleras themselves, but also generated further insights into loss and resistance to violence in global contexts. In this way, through this interactivity, an affective and tactile politics emerges as a powerful creative site for "knowing" and "doing" IR.

Focusing on five textiles that were featured in the exhibition has both highlighted the diversity of the textiles and elucidated the exhibition's central themes of resistance, the ethics of warfare, and migration and displacement. The textiles selected for discussion here stand out because they all work to transgress conventional assumptions of embroidered works, prompting us to consider instead the political potency of arpilleras in terms of their narratives, symbols, usage and intended audiences. Indeed, visitors to the exhibition remarked on the way that these seemingly everyday objects, nevertheless, seemed to speak loudly of resistance to violence. The reflection on the exhibition's bookmark further highlights the intertwining connections of voices, people and events within the exhibition and its curation. As Roberta remarks, the organising team at St Andrews cultivated this connection throughout by creating opportunities for the sharing of stories through conversation and making (see Cole, 2019). In each of these forms of interactivity - collaborative making, engaged looking and connective curating - the affective and tactile politics of engaging with conflict textiles were placed at the fore. In crafting space for connection and creation where this politics makes itself felt, conflict textiles emerge as a powerful creative site for "knowing" and "doing" IR differently.

Throughout the dialogue, we have revealed the wider communities of care which emerge through the textiles, as well as in their curating. Collaboration between the Threads team (as temporary custodians) and the Conflict Textiles permanent curatorial team helped to curate an exhibition whose legacies of collectivity, creativity and care of/for makers, curators, spectators and IR scholars continue to make themselves felt. In this way, curating the (hi) stories of conflict textiles contributes to alternative forms of IR knowledge production. Engaging with conflict textiles demands the unravelling and weaving together of their 
multiple narrative threads. Acting with these stories of loss, violence and its resistance, we argue that curating can form part of a process of embodied connection to stories of war and conflict that reach far beyond the academy. In this dialogue, we follow others (Andrä, Bliesemann de Guevara, Cole and House, 2020) in urging for future research into textile art as a language and methodology for the study of conflict, violence and resistance in IR. The exhibition and this dialogue present an alternative language for our study of IR, one that invites a more organic, emotional and tactile participation in politics based on the humble scraps of material we can all find at home.

1 For further information on Threads, war and conflict, see https://cain.ulster.ac.uk/ conflicttextiles/search-quilts2/fullevent1/?id=196 (Accessed: 2 August 2021).

2 For further information on the Conflict Textiles collection, see https://cain.ulster.ac.uk/ conflicttextiles/ (Accessed: 2 August 2021).

3 The term arpillera refers to stitched "textile pictures" (Andrä, Bliesemann de Guevara, Cole and House, 2020, p. 342). Originally made in Chile to document violence and resistance during the Pinochet dictatorship, the form has since been taken up in other contexts including Peru, Colombia, Zimbabwe and Northern Ireland.

4 For further information on Disobedient objects at the Victoria and Albert Museum, London, see: https://cain.ulster.ac.uk/conflicttextiles/search-quilts2/fullevent1/?id=129 (Accessed: 23 February 2021).

5 For further information on the \#NotABugSplat project and installation, see https:// notabugsplat.com/ (Accessed: 2 August 2021).

\section{Bibliography}

\#NotABugSplat collective (2014) 'A giant art installation targets predator drone operators', \#NotABugSplat [Online]. Available at: https://notabugsplat.com/(Accessed: 18 June 2021).

Andrä, C., Bliesemann de Guevara, B., Cole, L. and House, D. (2020) 'Knowing through needlework: curating the difficult knowledge of conflict textiles', Critical Military Studies, 6 (3-4), pp. 341-359.

Cole, L. (2019) Threads, war and conflict and its associated programme [Online]. Available at: $\quad$ https://cain.ulster.ac.uk/conflicttextiles/mediafiles/1321 Threads-War-and-ConflictPhoto-Essay-compressed-240619.pdf (Accessed: 18 June 2021). 


\section{Images}

Figures 1 and 2: University of St Andrews (2019) Master's workshops: responding to Threads, war and conflict: letters to arpilleristas [Poster]. Available at: https://cain.ulster.ac.uk/ conflicttextiles/mediafiles/1269 Masters-Workshops-Poster-final-240219.pdf (Accessed: 2 August 2021).

Figure 3: Anonymous (c1980) ¡Adiós Pinochet! / Goodbye Pinochet. [Arpillera, Chile], Conflict Textiles [Online]. Available at: https://cain.ulster.ac.uk/conflicttextiles/searchquilts2/fulltextiles1/?id=32 (Accessed: 2 August 2021).

Figure 4: Morales, V. (1989) La cueca sola / Dancing cueca alone [Arpillera, Chile], Conflict Textiles [Online]. Available at: https://cain.ulster.ac.uk/conflicttextiles/search-quilts2/ fulltextiles1/?id=414 (Accessed: 2 August 2021).

Figure 5: Stockdale, D. (2014) Digital death [Arpillera, Republic of Ireland], Conflict Textiles [Online]. Available at: https://cain.ulster.ac.uk/conflicttextiles/search-quilts2/ fulltextiles1/?id=279 (Accessed: 2 August 2021).

Figure 6: Campbell, T. and Campbell, I. (2012) It's no ******* computer game!! [Banner, Wales], Conflict Textiles [Online]. Available at: https://cain.ulster.ac.uk/conflicttextiles/ search-quilts2/fulltextiles1/?id=373 (Accessed: 2 August 2021).

Figure 7: Mansouri, F. (2017) LA BODA DE MI HIJA / My daughter's wedding [Arpillera, Catalonia/Spain], Conflict Textiles [Online]. Available at: https://cain.ulster.ac.uk/ conflicttextiles/search-quilts2/fulltextiles1/?id=410 (Accessed: 2 August 2021).

Figure 8: University of St Andrews (2019) Threads, war and conflict programme [Bookmark]. Available at: https://cain.ulster.ac.uk/conflicttextiles/mediafiles/1280 Threads-War-Conflictbookmarks-0319-DU37413.pdf (Accessed: 2 August 2021) 